\title{
Clinical stability of Fabry disease in 54 months' enzyme replacement therapy - follow-up of the first Polish study
}

\author{
Stanisława Bazan-Socha', Tomasz Miszalski-Jamka', Paweł Petkow-Dimitrow², Jacek Musiał ${ }^{1}$ \\ 1 II Department of Internal Medicine, Jagiellonian Universtity Medical College, Kraków, Poland \\ 2 II Department of Cardiology, Jagiellonian University Medical College, Kraków, Poland
}

\begin{abstract}
We present outcomes of 54 months' agalsidase $\beta$ enzyme replacement therapy of two 48- and 46 -year-old brothers with Fabry disease. The diagnosis was confirmed in 1997, and at that moment serious damage of internal organs was observed. During enzyme replacement therapy in both brothers the following changes were observed: amelioration of gastrointestinal symptoms, gain of body weight and reduction of cardiac hypertrophy on the ECG. In the older brother we observed: improvement in coronary blood flow, absence of angina pectoris, dyspnea, partial remission of headache and acroparaesthesia. Reduction of proteinuria, stabilization of creatinine clearance and appearance of perspiration were also noticed. In the younger brother, with a milder form of disease, we observed: improvement of hearing and vertigo, headache reduction, as well as stabilization of kidney function (although proteinuria was slightly increased). Unfortunately, acroparaesthesia and muscle pains in the legs became more severe. Enzyme replacement therapy in Fabry disease, even started in late adulthood, is effective by stabilizing organ functions and markedly improving quality of life.
\end{abstract}

Key words: agalsidase $\beta$, cardiac hypertrophy, chronic kidney disease, enzyme replacement therapy, Fabry disease

\section{INTRODUCTION}

Fabry disease ( $\alpha$-galactosidase A deficiency) is an inherited lysosomal storage disorder, characterized by the accumulation of glycosphingolipids, mainly globotriaosylceramide (GL-3) virtually in all tissues and organs. DNA region encoding agalactosidase is localized on chromosome X, locus q 22.11 . Males are mainly affected, but heterozygotic females can also be mildly symptomatic [1]. One case of a homozygotic female was described with severe symptoms of Fabry disease occurring at the age of 8 years [2]. In males initial clinical symptoms of the disease usually appear at school age and include: severe acroparaesthesia of upper and lower limbs, hypohidrosis and disturbances in thermoregulation. They might be joined some years later by angiokeratoma formation localized on the skin of hip, perineum and thighs, hypoacusis and gastro-intestinal symptoms (nausea, diarrhea and stomach pain). Progres-

Correspondence to:

dr med. Stanisława Bazan-Socha, II Katedra Chorób Wewnętrznych, Collegium Medicum Uniwersytetu Jagiellońskiego, ul. Skawińska 8, 31-066 Kraków, Poland, phone: +48-12-430-52-66, fax: +48-12-430-52-03, e-mail: mmsocha@cyf-kr.edu.pl

Received: May 28, 2007. Accepted in final form: July 11, 2007.

Conflict of interest: none declared.

Pol Arch Med Wewn. 2007; 117 (5-6): 260-265

Copyright by Medycyna Praktyczna, Kraków 2007 sive accumulation of glycosphingolipids in kidneys leads to the destruction of glomeruli (approx. at 30 years of age) and in the next decades to the development of end-stage renal failure [3]. Phenotype of the disease may vary. In some patients it may take a form limited to the heart and presenting mainly as a hypertrophic cardiomyopathy; especially frequent in heterozygotic women [3]. In others the disease may be limited to the isolated limbs acroparaesthesia [1,3]. For years only symptomatic treatment of Fabry disease was available. Life expectancy of such treated patients was decreased to about 40-50 years. The most frequent causes of death were renal insufficiency, stroke or myocardial infarction [3]. Starting from 2002 recombinant human $\alpha$-galactosidese became available for enzymatic replacement therapy (ERT) of Fabry disease. Two formulations are available: agalsidase $\alpha$ (Replagal, Shire, Cambrige, MA, USA) and agalsidase $\beta$ (Fabrazyme, Genzyme, Boston MA, USA). Results of multi-center studies indicate that ERT in Fabry disease may be effective $[4,5]$. These studies mainly showed a decrease of globotriaosylceramide levels in endothelial cells of the kidneys, heart and skin, accompanied by a stabilization of clinical symptoms and improvement in the quality of life [4,5].

In 1997, in our Department of Internal Medicine the diagnosis of Fabry disease was established in two adult males - brothers, at that time 38 and 36 years old. These patients 


\section{CASE REPORTS}

were already presented in detail in the previous issues of Polskie Archiwum Medycyny Wewnetrznej [6,7]. In May 2002 agalsidase $\beta$ ERT was started in both cases. Early effects of such treatment were described in the December 2004 issue [8]. The ERT was continued, and its results after four and a half years of such therapy are presented in this paper.

\section{CASE PRESENTATION}

Fabry disease was diagnosed in two adult brothers (S.J. born in 1959 and A.J. born in 1961), based on a very low activity of $\alpha$-galactosidase $\mathrm{A}$ in blood leukocytes (that is 0.12 $\mathrm{nmol} / \mathrm{mg}$ per hour in S.J. and $0.2 \mathrm{nmol} / \mathrm{mg}$ in AJ; ref. value $7.2 \pm 1.3)$. Mutation in the encoding region of enzyme was also identified (1235del115/insA).

\section{Enzyme replacement therapy}

Agalsidase $\beta$ was infused intravenously (duration approx. 5-7 h) every 2 weeks at a dose of $1 \mathrm{mg} / \mathrm{kg}$ of body weight. The older brother was also receiving a premedication (20-30 mg of metylprednisolone, i.v. and $1 \mathrm{~g}$ of acetaminphen) due to shivers and dyspnea during infusion.

The most significant clinical changes were observed in the first year of ERT. After that, the symptoms of Fabry disease stabilized. During the first year both brothers gained weight, and their temperature decreased to normal (tab.). S.J., but not A.J., reported the appearance of perspiration and better tolerance to heat. He noticed a distinct diminution of severe legs' acroparaesthesia. Opposite to his older brother, A.J. complained about initial deterioration of acroparaesthesia, which stabilized in the next few months. For several years before the initiation of ERT S.J. suffered from deep, narcotizing ulcerations leading to the formation of abscesses which involved skin, subcutaneous tissue and penetrated to the metatarsal bones of both feet. In the first months of ERT quick healing of the present ulcers was observed [8]. In the next years abscess formation reappeared, albeit with low frequency, and healed rapidly after surgical drainage. In the 18th month of therapy necrosis of the head of the V left metatarsal bone and in the 48th month necrosis of the head of the I right metatarsal bone required the surgical intervention with a partial bone amputation.

S.J. observed a distinct diminution of angina pectoris episodes during the first 6 months of ERT. Transthoracic echocardiography performed at the beginning of treatment revealed concentric, moderate hypertrophy of the left ventricle, together with the thickening of mitral and aortic leaflets and mild mitral regurgitation. The adenosine test $(140 \mu \mathrm{g} / \mathrm{kg} / \mathrm{min})$ showed a reduction in coronary blood flow in the left anterior descending artery. Recent echocardiography (January 2007) revealed similar left ventricular mass $\left(240 \mathrm{~g} / \mathrm{m}^{2}\right.$ of body surface area by Penn convention vs. 242 in the year 2003), but remarkable features of diastolic dysfunction with impaired relaxation $(\mathrm{E} / \mathrm{A}=$
0.95; DT 228 msec; LVIVRT $127 \mathrm{msec}$; Ar $0.43 \mathrm{~m} / \mathrm{sec}$; E'/A' 0.59). Furthermore, in comparison to 2003 a partial fusion of the commissures of the aortic valve and the narrowing of the surface area to $1.8 \mathrm{~cm}^{2}\left(3.9 \mathrm{~cm}^{2}\right.$ in 2003) were observed. After adenosine administration an improvement in coronary flow reserve was documented (2.4 vs 2.0 in 2003).

On the ECG lower voltage of QRS waves was noticed, but a possible regression of cardiac hypertrophy was not confirmed by echocardiography.

Opposite to the older brother, the younger one did not complained about any angina symptoms. Transthoracic echocardiography seemed to be unchanged, but because of the poor acoustic window a precise assessment was not possible. Like in the case of his older brother the ECG showed the decreased voltage of $\mathrm{R}$ and $\mathrm{S}$ waves. Additionally, the stable left boundle branch block (recurrent only in older ECGs) with a prolongation of PQ interval (0.1-0.12 s) was observed.

In both patients a moderate ventilatory impairment predominantly of the obstrucive type was observed by spirometry, which was not influenced by ERT (tab.).

In S.J. at the beginning of ERT we observed a reduction of daily proteinuria (4.5 to 1.5 ) which remained stable in the next years. Creatinine clearance also remained stable (tab.). In A.J. initially low proteinuria increased slightly and then stabilized (table). Serum creatinine concentration in both brothers increased, probably due to the higher body and muscle mass.

In S.J. after 14 months of ERT the paraparesis of all fourth limbs developed, more distinct proximally and in legs on the left side [8]. Additionally, the impaired superficial feeling and the sense of vibration in distal parts of both feet were observed. Many focal demielinisation changes and some dystrophic calcification in the nuclei of white matter (which were already present in 1999) were detected by MRI. Then all neurological symptoms diminished to the point where they did not disturb everyday activities. After 54 months of ERT S.J. reported a significant reduction in headaches and dizziness. Control MRI was similar to the one performed in 2003 .

ERT was not effective for neurological manifestations in A.J. In the 5th month of treatment he was hospitalized for an ischemic stroke to the left hemisphere (confirmed by CT) with hemiparesis and speech impairment [8]. Fortunately, almost all clinical symptoms disappeared during the next 3 months. In MRI small ischaemic foci dispersed throughout the entire brain were observed. In the first months of treatment the patient also complained about vertigo, the feeling of a "noise in the ears" and body imbalance. All these symptoms were interpreted as being of a vestibular origin [8]. In the next years neurological symptoms partially disappeared or stabilized. Recently performed brain MRI did not show any new ischemic or demielinisation changes.

A significant and rapid improvement in gastro-intestinal symptoms was noticed in both brothers. Abdominal pain, nausea and diarrhea appeared only occasionally and for a short time during these four and a half years.

In S.J. cataracts of both eyes developed due to the chronic steroid therapy started many years before the diagnosis of Fab- 
Table. Clinical and laboratory symptoms of Fabry disease before and during ERT in patients S.J. and A.J.

\begin{tabular}{|c|c|c|c|c|c|c|}
\hline \multirow[b]{2}{*}{ Parameters } & \multicolumn{2}{|c|}{ S.J. } & \multirow[b]{2}{*}{$\begin{array}{l}\text { After } 54 \\
\text { months }\end{array}$} & \multicolumn{3}{|c|}{ A.J. } \\
\hline & $\begin{array}{l}\text { Before } \\
\text { treatment }\end{array}$ & $\begin{array}{l}\text { After } 18 \\
\text { months }\end{array}$ & & $\begin{array}{l}\text { Before } \\
\text { treatment }\end{array}$ & $\begin{array}{l}\text { After } 18 \\
\text { months }\end{array}$ & $\begin{array}{l}\text { After } 54 \\
\text { months }\end{array}$ \\
\hline Body weight [kg] & 62 & 68 & 78 & 69 & 74 & 80 \\
\hline Acroparaesthesia (in legs) & ++++ & ++++ & +++ & ++++ & ++++ & +++++ \\
\hline Angiokeratoma & ++++ & ++++ & ++++ & ++++ & ++++ & ++++ \\
\hline Headache & ++++ & ++++ & +++ & ++++ & +++ & +++ \\
\hline Dizziness & +++ & +++ & ++ & ++++ & +++ & +++ \\
\hline Angina & ++++ & - & - & - & - & - \\
\hline Hypohidrosis & ++++ & +++ & ++ & +++++ & +++++ & ++++ \\
\hline Nausea & +++ & - & - & ++ & - & - \\
\hline Abdominal pain & +++ & + & + & + & + & - \\
\hline Dyspnea & ++++ & ++++ & +++ & ++++ & ++++ & ++++ \\
\hline Proteinuria [g/d] & 4.7 & 1.4 & 1.4 & 0.78 & 0.84 & 1.9 \\
\hline Creatinine clearance [ml/min] & 48 & 49 & 56 & 95 & 98 & 100 \\
\hline Creatinine blood level $[\mu \mathrm{mol} / \mathrm{l}]$ & 88 & 120 & 128 & 75 & 81 & 92 \\
\hline Blood albumin level [g/l] & 31 & 36 & 42 & 41 & 46 & 42 \\
\hline $\mathrm{FEV}_{1} \%$ & 68 & 57 & 65 & 50 & 50 & 46 \\
\hline Sokolov voltage index [mm] & 61 & 50 & 36 & 68 & 50 & 44 \\
\hline $\mathrm{P}-\mathrm{Q}[\mathrm{s}]$ & 0.12 & 0.12 & 0.12 & 0.08 & $0.1-0.12$ & $0.1-0.12$ \\
\hline $\mathrm{EF} \%$ & 60 & 55 & 60 & 65 & 61 & 60 \\
\hline
\end{tabular}

Sokolov voltage index: $R$ wave in $V_{5}+S$ wave in $V_{1}$. Subjective grading of symptoms from + to +++++ . Abbreviations: $E F-$ ejection fraction (in cardiac echocardiography), ERT - enzymatic replacement therapy, FEV 1 - forced expiratory volume in 1 second, P-Q - P-Q interval

ry disease. He was operated on both eyes with sight restoration. Already in 1999 abnormal blood vessels on the fundus of both eyes were observed (enlarged and braided). After four and a half years of ERT the picture remains unchanged.

No corneal degeneration, common to Fabry disease, was seen in the brothers.

A.J. eight years before the beginning of ERT lost the ability of hearing almost totally. Controlled audiogram performed in the 18th month of treatment confirmed a moderate hearing improvement. Recently audiogram shows the stable pattern of hearing.

In S.J. a mild, stable high frequency hearing impairment was observed.

Angiokeratomata in both subjects remain unchanged as concerns their number and localization. The picture of lymphedema of lower extremities is also stable.

\section{DISCUSSION}

We present clinical results of the long-term ERT using agalactosidase $A$ (agalsidase $\beta$ ) in two adult brothers with Fabry disease. The treatment was started in late adulthood - at the ages of 43 and 45, respectively, and was continued for four and a half years. This is the longest observation of the effects of such treatment in Poland and one of the longest in the world. Up to now most of the published cases cover periods of about 20-30 months. Generally, the results of ERT are worse for the older patients with chronic kidney disease than for the younger subjects [9]. However, ERT is nowadays considered the standard treatment for Fabry disease in all symptomatic cases [10]. At the beginning of our observation, both brothers were in the 5th decade of life and their disease was already in an advanced stage when the changes in the involved organs were most probably irreversible. Our observations confirm however that even if started so late ERT provides certain unquestionable benefits.

Cardiologic symptoms in Fabry disease are connected with: cardiac hyperthrophy, microvessels impairment and the pathologic function of heart conduction system (due to microfibrosis). In both brothers during ERT we observed a decrease of the high QRS complex voltage. We could not confirm the regression of cardiac hyperthrophy by echocardiography (progression was also excluded). In summary, these results indicated the stabilization of cardiac hypertrophy during four and 


\section{CASE REPORTS}

a half years of ERT. In the older brother symptoms of angina pectoris quickly disappeared, associated with an improvement in coronary artery blood flow. As epicardial vessels of both brothers appeared normal on coronarography $[6,8]$ the observed beneficial effect of ERT was most probably related to the improvement in endothelial function in microcirculation. ERT was, however, unable to slow down the process of heart valve damage. The efficacy of ERT on cardio-vascular symptoms in Fabry disease was described in 2003 by Waldek [11] and Weidemann [12]. Recently a regression of heart hypertrophy and a decreased risk of myocardial infarction after ERT have been reported [5]. These beneficial effects are limited to some patients only. In ERT of Fabry disease the prognostic value of cardiac MRI has been suggested [13]. This diagnostic procedure was unavailable in our patients.

The beneficial role of ERT for kidney function, most probably connected to the increased clearance of globotriasylceramides from tissue, has been reported [14-17]. In our patients the stabilization of kidney function seemed especially important. In the period preceding ERT the increase of proteinuria and fast progression of renal insufficiency was already observed in the older brother. In his 6th decade of life the patient's creatinine clearance is still around $50 \mathrm{ml} / \mathrm{min}$.

By spirometry both brothers showed mixed ventilatory impairment, predominantly obstruction, with frequent symptoms of upper respiratory tract infection in the older one. ERT had no effect on spirometry values. This is in accordance with the available literature [18]. However, a woman with chronic respiratory failure due to Fabry disease and a distinct improvement after ERT was recently described [19].

We are puzzled by a neurological deterioration observed in both brothers during the first months of treatment. Since new neurological complications as a result of ERT in Fabry disease have not been described, we tend to believe that they appeared in the natural course of the disease before ERT could have exerted a beneficial effect. Stabilization of neurological status of our patients during the next years of ERT reinforces this point of view. The effect of ERT on the central nervous system is debatable. While some observed new degenerative changes in the brain white matter [20], others noticed the improvement of peripheral nerves conduction [21].

Finally, other effects related to the 54-month-ERT included: total resolution of abdominal pain, chronic diarrhea and the improvement in the quality of life.

Unfortunately, we were not able to measure the level of sphingolipids and their possible clearance from tissues. However, it remains to be proven that there is a tight association between such clearance and the clinical response to the treatment. We also could not exclude that in both bothers some beneficial effects were related to concomitant chronic treatment, including ACE-ihibitors, statins and $\beta$-blockers.

In summary, the four and a half year of ERT with agalsidase $\beta$ shows beneficial effects on subjective and objective parameters of the disease in both brothers, especially the stabilization of kidney function, cardiac hypertrophy, CNS abnormalities and as a result the improvement in the quality of life.

\section{ACKNOWLEDGMENTS}

We thank Professor Anetta Undas for the kind consultation of the details of patients' history and for many valuable comments during the manuscript preparation.

We also appreciate the generosity of Genzyme Company who was providing Fabrazyme for free for both our patients during the entire period of their treatment.

\section{REFERENCES}

1. Brady R0, Schiffmann R. Clinical features of and recent advances in therapy for Fabry disease. JAMA. 2000; 284: 2771-2775.

2. Rodriguez-Mari A, Coll MJ, Chabas A. Molecular analysis in Fabry disease in Spain fifteen novel GLA mutations and identification of a homozygous female. Hum Mutat. 2003; 22: 258.

3. MacDermot KD, Holmes A, Miners AH. Anderson-Fabry disease: Clinical manifestations and impact of disease in a cohort of 98 hemizygous males. J Med Genet. 2001; 38: 750-760.

4. Eng CM, Guffon N, Wilcox WR, et al. Safety and efficacy of recombinant human alpha-galactosidase A replacement therapy in Fabry's disease. N Engl J Med. 2001; 345: 9-16.

5. Beck M, Ricci R, Widmer U, et al. Fabry disease: overall effects of agalsidase alfa treatment. Eur J Clin Invest. 2004; 34: 838-844.

6. Węgrzyn W, Undas A, Motyl R, et al. Choroba Fabry'ego - późne rozpoznanie u mężczyzny z przewlekłą nefropatią i zmianami skórnymi. Pol Arch Med Wewn. 1999; 101: 419-423.

7. Undas A, Ryś D, Węgrzyn W, et al. Nietypowe objawy choroby Fabry'ego - nagła obustronna utrata słuchu, obrzek limfatyczny i zespół Lowna, Ganonga i Levine'a. Pol Arch Med Wewn. 2002; 108: 1085-1090.

8. Undas A, Ryś D, Brzezińska-Kolarz B, et al. Pierwsze polskie doświadczenia z substytucyjną terapią enzymatyczną w chorobie Fabry'ego. Pol Arch Med Wewn. 2004; 112: 1479-1486.

9. Wilcox W, Banikazemi M, Guffon N, et al. Long-term safety and efficacy of enzyme replacement therapy for Fabry disease. Am J Hum Genet. 2004; 75: 65-74.

10. Desnick R, Brady $R$, Barranger J, et al. Fabry disease, an under-recognized multisystemic disorder: Expert Recommendation for diagnosis, management and enzyme replecement therapy. Ann Intern Med. 2003; 138: 338-346.

11. Waldek S. PR interval and the response to enzyme-replacement therapy for Fabry's disease. N Engl J Med. 2003; 348: 1186-1187.

12. Weidemann $F$, Breunig $F$, Beer $M$, et al. Improvement of cardiac function during enzyme replacement therapy in patients with Fabry disease: a prospective strain rate imaging study. Circulation. 2003; 108: 1299-1301.

13. Beer $M$, Weidemann $F$, Breunig $F$, et al. Impact of enzyme replacement therapy on cardiac morphology and function and late enhancement in Fabry's cardiomyopathy. Am J Cardiol. 2006; 98: 1557-1558.

14. Schiffmann R, Murray GJ, Treco D, et al. Infusion of alfa-galactosidase A reduces tissue globotriaosylceramide storage in patients with Fabry disease. Proc Natl Acad Sci USA. 2000; 97: 365-370.

15. Eng $\mathrm{CM}$, Banikazemi $\mathrm{M}$, Gordon $\mathrm{RE}$, et al. A phase $1 / 2$ clinical trial of enzyme replacement in Fabry disease: pharmacokinetic, substrate clearance and safety studies. Am J Hum Genet. 2001; 68: 711-722.

16. Schwarting A, Dehout F, Feriozzi S, Beck M, et al. Enzyme replacement therapy and renal function in 201 patients with Fabry disease. Clin Nephrol. 2006; 66: 77-84.

17. Thurberg BL, Rennke $H$, Colvin RB et al. Globotriaosylceramide accumulation in the Fabry kidney is cleared from multiple cell types after enzyme replacement therapy. Kidney Int. 2002; 62: 1933-1946.

18. Magage S, Lubanda JC, Germain DP, et al. Respiratory involvement in patients with Fabry disease. Med Sci. 2005; 21: 37-39.

19. Kim W, Pyeritz RE, Bernhardt BA, et al. Pulmonary manifestations of Fabry disease and positive response to enzyme replacement therapy. Am J Med Genet. 2007; 143: 377-381.

20. Jardim LB, Aesse F, Vedolin LM, et al. White matter lesions in Fabry disease before and after enzyme replacement therapy: a 2-year follow-up. Arq Neuropsiquiatr. 2006; 64: 711-717.

21. Jardim LB, Gomes I, Netto CB, et al. Improvement of sympathetic skin responses under enzyme replacement therapy in Fabry disease. J Inherit Metab Dis. 2006; 29: 653-659. 